\title{
The Effect of Teaching Models and Teaching Materials Towards Situational Interest
}

\author{
H. Ilmawati, A. Suherman \\ Sport Education Department \\ Post Graduate Program, Universitas Pendidikan Indonesia \\ Bandung, Indonesia \\ hilda_ilmawati@ymail.com
}

\begin{abstract}
The purpose of this research is to find out the effect of teaching models (inquiry and direct instruction) and teaching materials towards situational interest. The sample of the research was Class $X$ students at SMAN 1 Batujaya Karawang which was taken as random cluster sampling from 4 classes. The study uses a $2 \times 2$ factorial experimental design conducted over 16 meetings. Student's Situational Interest measured by using situational interest scale from Chen et al (2001) which had validity and reliability coefficients 0.718. Data was analysed using ANOVA. The findings showed that (1). Teaching models were not significantly giving the positive effect on situational interest, the significance values is 0.24 . (2). Teaching materials were significantly giving positive effect on student's situational interest, the significance value is 0.002 . (3). There was no significant relation between teaching models and teaching materials on student's situational interest, the significance value is 0.410 . Based on the result, it can be concluded that teaching materials were more able to arise student's interest rather than teaching models, meanwhile game material which had been taught by using inquiry model was teaching physical education which students more like. It needed to be more research on mixture models between teaching materials and teaching models.
\end{abstract}

Keywords: Inquiry Model, Games Teaching, Situational Interest

\section{INTRODUCTION}

The implementation of learning and teaching process in the curriculum 2013 is touching the whole domain of learning, which undertaken through sciencetific teaching model through each subject; it is no exception in physical education subject. Sciencetific learning is able to give a lot of positive effect for students. This is as set out in the opinion of Bruce Joyce and Marsha Weil (1996:42) “... scientific method can be taught and has positive effects on the acquisition of information, concepts, and attitudes". The hope of this curriculum is actually being facilitated in the aim of physical education. Psychomotor, affective, cognitive and social aspects are coverage in these subjects.

The use of teaching models is important factor in order to attempt educational goals achievement which is listed in the curriculum 2013. Many learning model can be used by teachers to achieve the objectives of the curriculum 2013. One of the learning model that can be used is inquiry teaching model.
Metzler (200:314) explained that "The inquiry model is strongly based in the cognitive domain, even for physical education instruction. Students are prompted into some level of thinking by the problem given to them by the teacher, solve the problem cognitively and then fashion a movement answer". that:

According to Adang Suherman (1998:131), He explained

Convergent problem solving or often referred to as discovery or inquiry, characterized by the presence of one or more correct answer to the problem posed by the teacher. In this style the students are actively involved in the use of logical reasons, critical thinking, and "trial and error" as an attempt to solve the problems faced.

The facts found in the learning process revealed that teaching physical education is dominated by direct instruction that is teacher-centered and not providing the opportunity for students to develop skills except psychomotor, so this approach is contrary to the expectations in the implementation of curriculum 2013 that hope the affective and cognitive aspects are being part of priority also in learning.

Refer to Metzler (200:162) "Direct Instruction is characterizied by decidedly teacher-centered decisions and teacher-directed engagement patterns for learners". Direct Instruction is good to use if teaching materials prioritize on motor skills. Psychomotor domains of learning outcomes better than inquiry. However, the learning is not holistic so that is not meaningful for students. It is as disclosed by Judith E. Rink (1993:165) "Direct Instruction is the best way to teach when content has a hierarchical structure and is primarly basic skilloriented".

Although in the theory, inquiry learning model described by Metzler widely used to promote student's affective domain and widely used by physical education teachers. The fact revealed there is no strong evidence that the inquiry teaching approach is able to increase student's affective domain. The use of inquiry models based solely on the belief of physical education teachers that inquiry learning model affect on student's affective domain. This is evidenced by the statement of Metzler (2000: 316): "This widespread use of inquiry teaching in physical education gives strong support for its effectiveness in promoting students thinking, creativity movement, and self esttem-all three of which appear to be growing as goals for contemporary physical 
education instruction. While research validation in physical education is lacking, it is difficult to ignore the fact that so many teachers use inquiry and problem solving approaches in their gyms."

Several studies revealed by Metzler has revealed the effectiveness of inquiry learning models in terms of the effectiveness of inquiry learning approach to improve the student's cognitive abilities. However, some studies have not revealed clearly the role of the inquiry learning approach to improve student's affective domain. Thus, the researcher want to test again to strengthen existing theories, which proposed by Metzler that inquiry learning model is able to influence the student's affective development.

One of the affective domain that researcher want to study is about student's situational interest. According to Gregory et al. (2001) "Situational Interest is defined as temporary interest that arises spontaneously due to environment factors such as task instruction or an engaging text".

Physical education teacher need to improve student's learning situational interest to provide attractive teaching, something new, challenging, so the students would be interested in trying to learn the task with spirit and do it with high motivation. Student's situational interest need to be developed in an effort to develop student's motivation to learn, so the student's learning outcomes are expected can be achieved better. Problem is often found in the learning physical education is student's situational interest in every meeting was unstable. The cause of the instability of situational interest is not known with certainty the cause. Based on these problems, the researcher wants to conduct research to strengthen the theory of Metzler about inquiry teaching model related to its effect on affective domain. In this study, the affective domain which the researcher tests is student's situational interest. In addition to test the effectiveness of Inquiry teaching models to the development of student's affective, the researcher also connects with teaching materials which are divided into 2 categories; game teaching materials and fundamental skills teaching materials.

From the description above, this study was conducted to determine:

1. Is there any situational interest difference between students who gain inquiry teaching models and direct instruction teaching models?

2. Is there any situational interest difference between students who gain games TeachingMaterials and fundamental skill Teaching Materials?

3. Is there any interaction between teaching models and teaching materials for differences on student's situational interest?

\section{METHOD}

This study was an experimental study. The design used was a $2 \times 2$ factorial design. The clearly mapping about 2 by 2 factorial design can be seen in the following table:
TABLE I. FACTORIAL DESIGN 2 X 2

\begin{tabular}{|c|c|c|}
\hline Learning Models & $\begin{array}{c}\text { Inquiry } \\
\text { (X1) }\end{array}$ & $\begin{array}{c}\text { Direct } \\
\text { Instruction } \\
\text { (X2) }\end{array}$ \\
\hline Lames / Basket Ball (Y1) & $\mathrm{X} 1 \mathrm{Y} 1$ & $\mathrm{X} 2 \mathrm{Y} 1$ \\
\hline Fundamental Skill / Sprint (Y2) & $\mathrm{X} 1 \mathrm{Y} 2$ & $\mathrm{X} 2 \mathrm{Y} 2$ \\
\hline
\end{tabular}

Procedure implementation in a $2 \times 2$ factorial design of this study is to use counterbalance experimental designs. The Counterbalance design implementation procedures as follows:

\begin{tabular}{|lcccccccc|}
\hline Group I & $\mathrm{X} 1$ & $\mathrm{O}$ & $\mathrm{X} 2$ & $\mathrm{O}$ & $\mathrm{X} 3$ & $\mathrm{O}$ & $\mathrm{X} 4$ & $\mathrm{O}$ \\
\cline { 2 - 9 } Group II & $\mathrm{X} 2$ & $\mathrm{O}$ & $\mathrm{X} 3$ & $\mathrm{O}$ & $\mathrm{X} 4$ & $\mathrm{O}$ & $\mathrm{X} 1$ & $\mathrm{O}$ \\
\cline { 2 - 9 } Group III & $\mathrm{X} 3$ & $\mathrm{O}$ & $\mathrm{X} 4$ & $\mathrm{O}$ & $\mathrm{X} 1$ & $\mathrm{O}$ & $\mathrm{X} 2$ & $\mathrm{O}$ \\
\cline { 2 - 9 } Group IV & $\mathrm{X} 4$ & $\mathrm{O}$ & $\mathrm{X} 1$ & $\mathrm{O}$ & $\mathrm{X} 2$ & $\mathrm{O}$ & $\mathrm{X} 3$ & $\mathrm{O}$ \\
\hline
\end{tabular}

Fig. 1. Counterbalanced Design (Sources: Fraenkel et al, 2012:275)

In more detail, the implementation of a counterbalance design in this study is described in the following Table:

TABLE II. Counterbalance Design

\begin{tabular}{|l|l|l|l|c|}
\hline \multirow{2}{*}{ CLASS } & \multicolumn{4}{|c|}{ MEETING } \\
\cline { 2 - 5 } & \multicolumn{1}{|c|}{$\mathbf{2}$} & $\mathbf{3}$ & $\mathbf{4}$ \\
\hline X IPA 1 & R X1Y1 O & R X2Y1 O & R X1Y2 O & R X2Y2 O \\
\hline X IPA 2 & R X2Y1 O & R X1Y2 O & R X2Y2 O & R X1Y1 O \\
\hline X IPA 3 & R X1Y2 O & R X2Y2 O & R X1Y1 O & R X2Y1 O \\
\hline X IPA 4 & R X2Y2 O & R X1Y1 O & R X2Y1 O & R X1Y2 O \\
\hline
\end{tabular}

The researcher conducted a random assignment for material selection and learning models that will be given to four groups of samples. The research program implementation is as follows:

TABLE III. THE RESEARCH PROGRAM IMPLEMENTATION BASED ON RANDOM ASSIGNMENT

\section{RESULT}

\begin{tabular}{|c|c|c|c|c|c|c|c|c|}
\hline No & $\begin{array}{c}\mathbf{X} \\
\mathbf{A} \\
\mathbf{1} \\
\end{array}$ & Date & $\begin{array}{c}\mathbf{X ~ A} \\
2\end{array}$ & Date & X A 3 & Date & XA 4 & Date \\
\hline 1 & $\begin{array}{l}\text { X1 } \\
\text { Y1 }\end{array}$ & $\begin{array}{l}08- \\
03- \\
2014\end{array}$ & $\begin{array}{l}\mathrm{X} 2 \mathrm{Y} \\
1\end{array}$ & $\begin{array}{l}\begin{array}{l}13- \\
04- \\
2014\end{array} \\
\end{array}$ & $\mathrm{X} 1 \mathrm{Y} 2$ & $\begin{array}{l}28-02- \\
2014\end{array}$ & $\mathrm{X} 2 \mathrm{Y} 2$ & $\begin{array}{l}14- \\
03- \\
2014\end{array}$ \\
\hline 2 & $\begin{array}{l}\mathrm{X} 2 \\
\mathrm{Y} 1\end{array}$ & $\begin{array}{l}05- \\
04- \\
2014\end{array}$ & $\begin{array}{l}X 1 Y \\
2\end{array}$ & $\begin{array}{l}\text { 03- } \\
04- \\
2014\end{array}$ & $\mathrm{X} 2 \mathrm{Y} 2$ & $\begin{array}{l}07-03- \\
2014\end{array}$ & $\mathrm{X} 1 \mathrm{Y} 1$ & $\begin{array}{l}\text { 05- } \\
04- \\
2014\end{array}$ \\
\hline 3 & $\begin{array}{l}\text { X1 } \\
\text { Y2 }\end{array}$ & $\begin{array}{l}15- \\
03- \\
2014 \\
\end{array}$ & $\begin{array}{l}X 2 Y \\
2\end{array}$ & $\begin{array}{l}10- \\
04- \\
2014\end{array}$ & X1Y1 & $\begin{array}{l}14-03- \\
2014\end{array}$ & $\mathrm{X} 2 \mathrm{Y} 1$ & $\begin{array}{l}28- \\
02- \\
2014 \\
\end{array}$ \\
\hline 4 & $\begin{array}{l}\mathrm{X} 2 \\
\mathrm{Y} 2\end{array}$ & $\begin{array}{l}01- \\
03- \\
2014 \\
\end{array}$ & $\begin{array}{l}\mathrm{X} 1 \mathrm{Y} \\
1\end{array}$ & $\begin{array}{l}27- \\
02- \\
2014\end{array}$ & $\mathrm{X} 2 \mathrm{Y} 1$ & $\begin{array}{l}07-03- \\
2014\end{array}$ & $\mathrm{X} 1 \mathrm{Y} 2$ & $\begin{array}{l}07- \\
03- \\
2014 \\
\end{array}$ \\
\hline
\end{tabular}

Data presented contains the average and standard deviation of situational interest. Meanwhile on the hypothesis testing part, which contained statistical prerequisite testing and hypothesis testing of three hypotheses have been formulated. 
TABLE IV. MEAN SCORE (X) AND STANDARD DEVIATION (SD) SITUATIONAL INTEREST IN EACH EXPERIMENTAL GROUP

\begin{tabular}{|l|l|l|l|}
\hline \multirow{2}{*}{$\begin{array}{c}\text { Learning } \\
\text { Materials }\end{array}$} & \multicolumn{2}{|c|}{ Learning Models } & \multirow{2}{*}{ Combination } \\
\cline { 2 - 3 } & \multicolumn{1}{|c|}{ Inquiry } & \multicolumn{1}{c|}{ Direct Instruction } & \\
\hline Games & $\begin{array}{l}\mathrm{x}=101.71 \\
\mathrm{sd}=7.41\end{array}$ & $\begin{array}{l}\mathrm{x}=101.34 \\
\mathrm{sd}=7.43\end{array}$ & $\begin{array}{l}\mathrm{x}=101.53 \\
\mathrm{sd}=7.42\end{array}$ \\
\hline $\begin{array}{l}\text { Fundamental } \\
\text { Skill }\end{array}$ & $\begin{array}{l}\mathrm{x}=99.81 \\
\mathrm{sd}=8.77\end{array}$ & $\begin{array}{l}\overline{\mathrm{x}}=98.08 \\
\mathrm{sd}=8.65\end{array}$ & $\begin{array}{l}\overline{\mathrm{X}}=98.945 \\
\mathrm{sd}=8.71\end{array}$ \\
\hline Combination & $\begin{array}{l}\mathrm{x}=100.76 \\
\mathrm{sd}=8.03\end{array}$ & $\begin{array}{l}\mathrm{x}=99.71 \\
\mathrm{sd}=8.21\end{array}$ & \\
& & & \\
& & & \\
& & &
\end{tabular}

\section{A. Assumption Test Statistics Test of Normality}

Test of normality used in this study is Shapiro-Wilk test at significance level $a=0,05$ according to the provisions of Nisfiannoor (2009:94) is, "when the $\mathrm{P}$ value $>0.05$ then the data is normal, whereas when $\mathrm{P}$ value $<0,05$ then the data is abnormal". The following are the results of normality test of Situational Interest data in the different treatment groups.

TABLE V. Situational INTEREST NoRmality TEST RESUlts

\begin{tabular}{|l|l|l|l|}
\hline \multirow{2}{*}{ Treatment } & \multicolumn{3}{|c|}{ Shapiro - Wilk } \\
\cline { 2 - 4 } & \multicolumn{1}{|c|}{ Statistic } & \multicolumn{1}{c|}{ Df } & Sig \\
\hline Direct Games (DG) & 0.985 & 95 & 0.335 \\
\hline Direct Skill (DS) & 0.987 & 95 & 0.449 \\
\hline Inquiry Games (IG) & 0.974 & 95 & 0.052 \\
\hline Inquiry Skill (IS) & 0.988 & 95 & 0.568 \\
\hline
\end{tabular}

\section{B. Homogeneity Test}

Homogeneity test was done with Levene test. The following are the results of homogeneity test using the Levene's test:

TABLE VI. Homogeneity Data Test Results

\begin{tabular}{|l|l|l|l|l|l|}
\hline \multicolumn{2}{|c|}{} & Levene Statistic & \multicolumn{1}{|c|}{ df1 } & \multicolumn{1}{c|}{ df2 } & \multicolumn{1}{c|}{ Sig. } \\
\hline \multirow{4}{*}{ SI } & Based on Mean & 1.593 & 3 & 376 & 191 \\
\cline { 2 - 6 } & Based on Median & 1.683 & 3 & 376 & 170 \\
\cline { 2 - 6 } & $\begin{array}{l}\text { Based on Median and with } \\
\text { adjusted df }\end{array}$ & 1.683 & 3 & 366.2 & 170 \\
& & & 25 & \\
\cline { 2 - 7 } & Based on trimmed mean & 1.641 & 3 & 376 & 179 \\
\hline
\end{tabular}

Interpretation was done by selecting one of the statistics that based on the statistical average (Based on Mean). Based on the table 6 it gained significance or probability value is 0,191 significant value when compared with a 0,05 is greater $(0,191$ $>0,05)$. So, it can be concluded that the data come from populations having the same variance.

\section{Statistics Test}

1) Situational Interest differences between students who earn Inquiry Learning Models and Direct Instruction Learning Models.
The analysis technique used is a 2 factor ANOVA interaction.

Hypothesis:

Ho: There is no situational interest difference, between students who earn inquiry learning models and direct instruction learning models.

H1: There is situational interest difference, between students who earn inquiry learning models and direct instruction learning models.

Decision Making:

- If the probability $>0,05$, then Ho is accepted

- If the probability $<0,05$, then Ho is rejected

The results are as follows:

TABLE VII. CALCULATION RESULTS OF THE ANOVA LEARNING MODELS FACTOR

\begin{tabular}{|l|l|l|l|l|l|}
\hline \multicolumn{1}{|c|}{ Source } & Type III Sum of Squares & Df & $\begin{array}{c}\text { Mean } \\
\text { Square }\end{array}$ & F & Sig. \\
\hline Learning & 104.213 & 1 & 104.213 & 1.616 & 204 \\
\hline Models & & & \\
\hline
\end{tabular}

a. Dependent Variable: Situational Interest

Based on the calculation results of the analysis of variance about the difference between the effect of inquiry learning models and direct instruction learning models on situational interest, it is known that there is no situational interest difference, between students who earn inquiry learning models and direct instruction learning models.

2) Situational Interest Differences Between Students Who Get The Games Learning Materials And Fundamental Skill Learning Materials.

The analysis technique used is a 2 factor ANOVA interaction.

Hypothesis:

Ho: There is no situational interest difference, between students who get the games learning materials and fundamental skill learning materials.

$\mathrm{H} 1$ : There is situational interest difference, between students who get the games learning materials and fundamental skill learning materials.

Decision Making:

- If the probability $>0,05$, then Ho is accepted

- If the probability $<0,05$, then Ho is rejected

The results are as follows:

TABLE VIII. CAlculation Results of THE ANOVA Two Factor INTERACTIONS

\begin{tabular}{|c|c|c|c|c|c|}
\hline Source & $\begin{array}{c}\text { Type III Sum of } \\
\text { Squares }\end{array}$ & Df & $\begin{array}{c}\text { Mean } \\
\text { Square }\end{array}$ & F & Sig. \\
\hline Learning Materials & 629.266 & 1 & 629.266 & 9.757 & .002 \\
\hline
\end{tabular}


Based on calculation results of the ANOVA on table 8, it is known that there is Situational interest difference, between students who get the games learning materials and fundamental skill learning materials. Based on the table above, it is known that $F$ value $=9.757$ and significance $=0,002<0,05$. It means that $\mathrm{H} 1$ which state that there is situational interest difference, between students who get the games learning materials and fundamental skill learning materials is accepted.

3) The Interaction between Learning Models and Learning Materials On Situational Interest.

The analysis technique used is a 2 factor ANOVA interaction.

Hypothesis:

Ho: There is no significant interaction between learning models and learning materials on situational interest.

H1: There is interaction between learning models and learning materials on situational interest.

Decision Making:

- If the probability $>0,05$, then Ho is accepted

- If the probability $<0,05$, then Ho is rejected

The results are as follows:

TABLE IX. THE RESULTS OF THE ANOVA Two FACTOR INTERACTIONS

\begin{tabular}{|l|l|l|l|l|l|}
\hline \multicolumn{1}{|c|}{ Source } & \multicolumn{1}{c|}{$\begin{array}{c}\text { Type III Sum of } \\
\text { Squares }\end{array}$} & Df & Mean Square & \multicolumn{1}{|c|}{ F } & Sig. \\
\hline Corrected Model & $777.271 \mathrm{a}$ & 3 & 259.090 & 4.017 & .008 \\
\hline Intercept & 3817820.845 & 1 & 3817820.845 & 59198.626 & .000 \\
\hline MODEL & 104.213 & 1 & 104.213 & 1.616 & .204 \\
\hline MATERIALS & 629.266 & 1 & 629.266 & 9.757 & .002 \\
\hline MODEL $* 43.792$ & 1 & 43.792 & .679 & .410 \\
MATERIALS & & & & & \\
\hline Error & 24248.884 & 376 & 64.492 & & \\
\hline Total & 3842847.000 & 380 & & & \\
\hline Corrected Total & 25026.155 & 379 & \multicolumn{3}{c|}{} \\
\hline
\end{tabular}

Based on the calculation results of the analysis of variance (ANOVA) it is obtained $\mathrm{F}$ value $=0,679$ and $\mathrm{P}=0,410>0,05$. It means that Ho is accepted and H1 is rejected. So, there is no significant interaction between learning models and learning materials on situational interest differences.

\section{DISCUSSION}

\section{A. The Situational Interest Differences between Students Who Earn Inquiry Learning Models and Direct Instruction Learning Models.}

Rejection of the first hypothesis indicates that the inquiry learning models and direct instruction learning models do not give significantly different effect on the situational interest, but in between these two models learnings, inquiry learning models gave better effect to the situational interest. It can be shown by the difference in the situational interest average score. Either in both the games and skills teaching materials, acquisition of situational interest better when treatment is given to the inquiry learning models in comparison with the direct instruction learning models. Based on these findings, several possible causes for rejection of the first hypothesis, as follows:

1. The process of implementation of the learning of both learning approaches.

2. The level of student's intelligence.

3. The characteristics of rural students.

4. The competence of teachers in teaching needs to be improved.

Inquiry learning models provide great chances to increase student's situational interest. A good situational interest will affect student's motivation in the short term. The consistency of use of learning models can improve situational interest in each meeting will affect the student's motivation in the long term. However, the application process of the inquiry learning models is different from direct instruction learning implementation. In inquiry learning models students are directed to be able to solve the problem of motion cognitively. Students will be given a variety of problems and given the opportunity freely to hypothesize the answers found. This process means that inquiry learning models has a huge challenge; students no longer have to move the "imitative" as exemplified by the teacher in direct instruction model.

The challenge contained in the inquiry learning models can affect student engagement in learning activities. An active engagement in learning will affect the enjoyment of students and can improve student's situational interest. The involvement of students in the group will also affect on attention demand, which finally will affect the student's situational interest. According to Chen et al "In the interactive experience category, the dimensional sources include Attention Demand ... that are occurring when the person engages with the activity".

Another aspect that is contained in the inquiry learning models that can improve situational interest is intention exploration. Unimpeded opportunity to students to seek answers to the problems of motion is given to improve student's exploration intention. Refers to Chen et al:"Exploration Intention had positive effects that led students to experience instant enjoyment and eventually to feel interested in an activity."

Conceptually, inquiry learning models likely to increase student's situational interest. However, the inquiry learning models dominated by cognitive aspects of students. Student's skills in reasoning, found the problem, trying to find answers and simulate the response need to be owned by students. Intelligence level greatly affects student's ability to solve cognitively. Good intelligence of students will affect the quality of student's cognitive. Meanwhile, would be difficult if the scientific learning models were given to students who have low intelligence level. Wina Sanjaya (2008:126) "Cognitive domain is the aim of education which is associated with intellectual ability or abilities, thinking, such as the ability to recall and problem-solving skills". 
The sample in this study allegedly not used to learn the process of learning methods that are scientific. So the cognitive aspects of students to solve problems of movement are not developing. When students given the opportunity to solve the problem of motion, students are hard to find problems and feel difficult to find the answer. Students tend to be silent without trying to discuss searching for answers to the problems of motion given. This is the case that led to significant situational interest difference when students are given different treatments learning models.

Other allegations that led to significant influence between learning models with situational interest is inquiry learning models that expressed by Metzler have the same interests with direct instruction learning models on student's situational interest. So, a different provision of learning models does not provide a significant difference in the results of the students' situational interest.

The rural community characteristics are paternalistic. According to Didin Budiman (2009:144) "the core paternalistic characteristics are considered parents as everything, such as the most understanding and which determines what should be done by the young man".

This paternalistic characteristic suspected to be the cause of the model of inquiry learning objectives is not achieved. Students are happier if given learning with a method of direct instruction, more students believe that all movements in the psychomotor learning undertaken by teachers are entirely right and proper. Students are not critical to the problems of motion that they might find in learning. Due to the existence of this character, situational interest becomes difficult developed with inquiry learning models which is focusing student's intellectual abilities.

Another thing that contributed is the researcher's competence as a teacher in this study that need to be increased more. The use of inquiry learning models considered as new things for the researcher, although the researcher has tried to optimal as possible, but the researcher believes that there are some shortcomings that need to be repaired. So that the shortcomings in the teaching influences the results in this study.

\section{B. Situational Interest Differences Between Students Who Get The Games Learning Materials And Fundamental Skill Learning Materials.}

Hypothesis test results showed that the learning materials have a significant influence on differences in student's situational interest. Games learning materials gives a better effect to the situational interest compared to student's fundamental skills learning materials. Whatever models learning is, if the learning materials is games then the situational interest can be affected significantly.

Games learning materials can give a better effect because the games learning materials provide opportunities for students to interact in a group. Games consist of 2 or more students and they joined in the motion to perform activities in the form of a game. In this research, games learning materials represented by basketball material. Students are given the opportunity to play and interact widely with their friends in group. The Form of games can be modified so that the opportunity to explore is very high. This will certainly affect the student's intention exploration. Students who have a high intention exploration would be more interested in learning.

In a game learning materials, students are given the opportunity to actualize the fundamental skills that have been studied previously. Students will be trained their confidence in playing the game in the group. Students are given the opportunity to try out their skills in a fundamentally different game situation. When students feel able to do a good performance in a game, then the aspects of their confidence will grow. David E. Belka (1994:10) "to foster a special confidence for movement in a child, you must build the child's selfconfidence concurrently with movement competence".

Learning materials in games, game situation is unpredictable, it would pose a challenge to the students. Students will be motivated to continue to move in the game and try to resolve these challenges. When learning contains challenges, then this will encourage student's interest in learning and increase student's situational interest.

\section{The Interaction between Learning Models and Learning Materials on Situational Interest.}

Hypothesis test results show that there is no significant interaction between learning models and learning materials on situational interest. learning models, either inquiry or direct instruction do not provide a significant positive effect on student's situational interest. Meanwhile learning materials have a significant influence on student's situational interest. Games learning materials provide a more significant effect than the fundamental skills of the learning materials situational interest. Learning models and learning materials are not yet simultaneously capable of affecting the situational interest students significantly.

Different learning models do not give interest to the students when compared with the learning materials. Although the inquiry learning models learning models that are scientific, inquiry learning models of Metzler does not contribute significantly to the situational interest in this study. Therefore, it needed to use other scientific learning models to improve student's situational interest. Adang Suherman (2009:150) said that indirect instruction types including "problem solving (guided discovery and divergent discovery), learner's design, learner-initiated, and self-teaching style".

\section{CONCLUSION AND RECOMMENDATION}

\section{A. Conclusion}

Based on the results of processing and analysis data, and then obtained answer research questions posed. The conclusion from above research questions are as follows:

1. Teaching models provides positive effect but not significant on student's situational interest. Inquiry teaching models give a positive influence better than direct instruction teaching models.

2. Teaching materials provides significant positive effect on student's situational interest. Games teaching materials give a positive influence better than teaching materials skill. 
3. There is no significant interaction effect between teaching models (inquiry and direct instruction) and teaching materials (games and fundamental skill) on situational interest. The influence of teaching models on situational interest is not affected by teaching materials and vice versa.

In general, the results of this study can be summarized as follows:

1. The phenomenon of student's interest to games teaching materials in teaching physical education is not deterred by the emergence of inquiry teaching models as advocated in the curriculum in 2013.

2. The combination of games teaching materials and inquiry teaching models is the best model based on the results of this study, it can be used as an innovation that should be investigated further through other scientific approaches as recommended curriculum in 2013.

\section{B. Recommendation}

Based on the conclusion of the study, the researcher proposed some recommendations for teachers of physical education and further research:

1. Teachers are expected to implement teaching models that are scientific at the most basic education level. So at the high school level, students will not have difficulty when faced with the teaching of scientific.

2. This study provides the opportunity for further research to investigate the involvement of other scientific teaching models. There are many scientific teaching models other than inquiry teaching models those described in this study.

3. Several factors have influenced the results of this study, such as intelligence level and characteristics of rural students. Therefore, further research may involve factors of intelligence and character of students in research related to the inquiry teaching models and situational interest.

4. It needed the hybrid model teaching innovation research (mix) between teaching materials games with other scientific teaching models as recommended in curriculum in 2013.

5. Teacher delivered fundamental skill teaching materials with the games characteristics, so that in the implementation of any situational interest teaching materials the students remain can be developed.

\section{ACKNOWLEDGMENT}

Special thanks are extended to Prof. Dr Adang Suherman, MA for advice on aspects of the research and to Drs. Agus Setiawan, M.Pd as a Principal of SMAN 1 BATUJAYA for the opportunities to work with the students.

\section{REFERENCES}

[1] Belka, E. david. (1994). Teaching Children Games. Ohio: Human Kinetics Publisher, Inc.

[2] Budiman, Didin.(2009). Model Pengembangan Proses Sosial Siswa SD Melalui Metode and Pendekatan Mengajar Physical education. Tesis, Sekolah Pascasarjana, Universitas Pendidikan Indonesia.

[3] Fraenkel, J.R. (2012). How To Design And Evaluate Research In Education. USA :Mc Graw Hill.

[4] Graham Goerge, Holt/Hale Shirley, and Parker Melissa.(1993). Children Moving, A Reclective Approach to Teaching Physical Education. California: Mayfield Publishing Company

[5] Joyce, B and Weil, M.(1996). Models of teaching, fifth edition. Boston : Allyn and Bacon

[6] Metzler, W M. (2000). Intructional Models For Physical Education. Goergia State University.

[7] Nisfiannoor, M. (2009). Pendekatan Statistik Modern Untuk Ilmu Sosial. Jakarta: Salemba Humanika

[8] Rink, E Judith. (1993). Teaching Physical Education for Learning. Missouri: Mosby-Year Book,Inc.

[9] Sanjaya, W. (2008). Perencanaan dan Desain Sistem Pembelajaran. Jakarta : Fajar Inter Pratama.

[10] Suherman, A.(2009). Revitalisasi Keterlantaran Pengajaran Physical education. Bandung: Universitas pendidikan Indonesia.

[11] Ang Chen, Paul W. Darts and Robert P. Pangrazi.(2001). An Examination of Situational Interest and Its Sources. Journal of British Journal of Educational Psychology (2001).

[12] Gregory Schraw, Terry Flowerday, and Stephen Lehman. (2001). Increasing Situational Interest in the Classroom. Journal of Educational Psychology Review, Vol 13, No 13,2001. 